\title{
PENGARUH PERBAIKAN KONDISI TANAH TERHADAP PERTUMBUHAN \\ KALIANDRA (Calliandra calothyrsus) DAN BUNI (Antidesma bunius) DI KAWASAN KONSERVASI GUNUNG BATUR, BALI \\ (The Effect of Soil Condition Improvement on Calliandra calothyrsus and Antidesma bunius Growth in Batur Mountain Conservation Area, Bali)*
}

\author{
Budi Hadi Narendra ${ }^{1}$ \\ Pusat Litbang Konservasi dan Rehabilitasi \\ Jl. Gunung Batu No. 5 Po Box 165; Telp. 0251-8633234, 7520067; Fax 0251-8638111 Bogor;

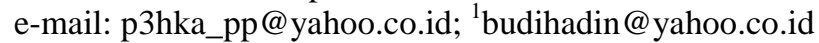 \\ *Diterima: 22 Agustus 2011; Disetujui: 3 Agustus 2012
}

\begin{abstract}
Batur Mountain conservation area which is part of the forest group of Gunung Batur - Bukit Payang has important values in supporting Batur Lake sustainability and the surrounding community life. The forest area of Batur Mountain is 2,528 ha dominated by very critical land which covered by sand and lava clots. Various efforts to rehabilitate the degraded land in this area have been carried out but the result was limited in certain species, especially on the land with deep enough solum. This study was conducted to see the effects of soil condition improvement by increasing the organic matter on early growth of Calliandra calothyrsus Meisn. and Antidesma bunius (L.) Spreng. The trial used completely randomized block design and the given treatments were the addition of chicken manure and top soil in the planting holes. The observations made in the third year showed a significant response of the chicken manure application to the plant growth. The manure addition treatment can increase soil $N$ and $P$ contents 46 and 10 times consecutively compared to the control and highly correlated to the plant growth.
\end{abstract}

Keywords: Soil conditions, manure, top soil, conservation area

\begin{abstract}
ABSTRAK
Kawasan konservasi Gunung Batur yang termasuk dalam kelompok hutan Gunung Batur - Bukit Payang (RTK 7) memiliki nilai penting dalam menyangga kelestarian Danau Batur dan kehidupan masyarakat sekitarnya. Kawasan hutan seluas 2.528 ha ini didominasi lahan dengan kriteria sangat kritis akibat tutupan lahan yang didominasi pasir dan bekuan lava. Berbagai upaya rehabilitasi telah dilakukan namun keberhasilannya terbatas hanya pada jenis tanaman tertentu terutama pada lahan dengan solum yang cukup dalam. Penelitian ini berupaya melakukan perbaikan kondisi tanah melalui peningkatan bahan organik dan melihat pengaruhnya terhadap pertumbuhan tanaman jenis kaliandra (Calliandra calothyrsus Meisn.) dan buni (Antidesma bunius (L.) Spreng). Ujicoba dilakukan dengan rancangan acak lengkap berblok, perlakuan yang diberikan adalah penambahan pupuk kandang dari kotoran ayam dan top soil pada lubang tanam. Pengamatan yang dilakukan pada tahun ketiga menunjukkan adanya respon nyata dari penambahan pupuk kandang terhadap perbaikan kondisi tanah dan pertumbuhan tanaman. Perlakuan pemberian pupuk kandang mampu meningkatkan kandungan $\mathrm{N}$ dan $\mathrm{P}$ tanah masing-masing sebanyak 46 dan 10 kali lipat dibandingkan kontrol dan berkorelasi kuat dengan pertumbuhan tanaman.
\end{abstract}

Kata kunci: Kondisi tanah, pupuk kandang, top soil, kawasan konservasi

\section{PENDAHULUAN}

Kawasan hutan di Gunung Batur yang berfungsi sebagai hutan konservasi dan hutan produksi terbatas, memiliki nilai penting dalam menyangga kelestarian Danau Batur dan kehidupan masyarakat di sekitarnya. Puluhan kali erupsi yang pernah terjadi, menghasilkan tutupan lahan yang didominasi oleh pasir dan batuan volkanik. Hingga tahun 2008 luas lahan kritis di sekitar Gunung Batur mencapai 3.565,51 ha atau sekitar 2,24\% dari total luas lahan kritis di Provinsi Bali. Dari luasan tersebut, di dalamnya terdapat kawasan hutan Gunung Batur seluas 2.528 ha yang didominasi lahan dengan 
kriteria sangat kritis (Bappeda Provinsi Bali, 2009) sehingga lokasi ini menjadi salah satu prioritas untuk rehabilitasi hutan dan lahan.

Rehabilitasi lahan pada prinsipnya meliputi aspek saintifik, aspek teknologi, dan aspek aplikasi. Aspek saintifik ditempuh melalui dua pendekatan yaitu proses di dalam tanah (proses biogeokimia) dan proses di atas tanah (proses suksesi tumbuhan). Proses biogeokimia melibatkan mikroba tanah dan ketersediaan bahan organik serta dipengaruhi faktor klimatik. Proses suksesi tumbuhan dapat terjadi secara alami namun memerlukan waktu yang lama (25-100 tahun). Dengan penerapan aspek teknologi, diharapkan suksesi dapat berjalan lebih cepat. Teknologi yang dipilih harus tepatguna yaitu mudah, murah, efektif, dan efisien seperti penggunaan pupuk organik, mikroorganisme tanah, dan tanaman legum (Supriyanto, 2002). Berbagai upaya rehabilitasi lahan kritis di kawasan ini telah dilakukan namun keberhasilannya terbatas untuk jenis tanaman tertentu seperti ampupu (Eucalyptus urophylla ST.Blake) dan pinus (Pinus merkusii Jungh.\& De $\mathrm{Vr}$ ) pada lahan dengan solum yang cukup dalam. Hal ini disebabkan oleh minimnya unsur hara yang tersedia bagi tanaman, ditambah kondisi curah hujan yang rendah menyebabkan tanah dengan dominansi pasir sangat terbatas dalam menyuplai air bagi tanaman. Upaya yang dapat ditempuh untuk meningkatkan keberhasilan rehabilitasi lahan adalah dengan memperbaiki kondisi tanah melalui peningkatan bahan organik.

Penelitian ini bertujuan mengujicobakan perbaikan kondisi tanah melalui peningkatan bahan organik dengan menambahkan pupuk kandang dan/atau top soil pada media tanam. Analisis dilakukan terhadap perubahan kondisi tanah dan pengaruhnya terhadap pertumbuhan dua jenis tanaman yaitu kaliandra (Calliandra calothyrsus Meisn.) dan buni (Antidesma bunius (L.) Spreng).

\section{BAHAN DAN METODE}

\section{A. Waktu dan Lokasi Penelitian}

Penelitian ini mulai dilaksanakan tahun 2008. Pengamatan terakhir telah dilakukan pada tahun 2010. Penelitian dilaksanakan di lereng Gunung Batur yang secara administrasi terletak di Desa Batur Tengah, Kecamatan Kintamani, Kabupaten Bangli, Provinsi Bali. Gunung Batur terletak di Pulau Bali pada posisi geografis $08^{\circ} 14$ '30" Lintang Selatan dan $115^{\circ} 22^{\prime} 30 ”$ Bujur Timur. Puncak Gunung Batur pada saat ini terletak pada ketinggian $1.717 \mathrm{~m} \mathrm{dpl}$. Gunung Batur pernah mengalami 26 kali erupsi besar sejak tahun 1804 sampai 2000. Letusan terhebat terjadi pada 1926, dimana lava yang keluar mengubur seluruh Desa Batur Kuno yang terletak di kaki gunung (Badan Pengelola Gunung Api Batur, 2009). Pusat Vulkanologi dan Mitigasi Bencana Geologi (2010) menyatakan status Gunung Batur mengalami peningkatan dari normal menjadi waspada sejak 8 November 2009 hingga 19 November 2010.

Permukaan lahan pada lokasi penelitian umumnya bergelombang dengan didominasi bekuan lava. Berdasarkan Peta Geologi Kaldera Batur, lokasi penelitian berada pada leleran lava tahun 1888 . Leleran yang membeku membentuk batuan jenis Andesite basaltic berwarna abu-abu sampai abu-abu kehitaman, bersifat masif dan sebagian vesikuler dengan bentuk permukaannya tidak teratur dan skorian, mengandung $35 \%$ plagioklas $(<2$ $\mathrm{mm}$ ), olivin dan klinopiroksin dengan banyak butiran oksida besi. Ketebalannya mencapai 3-10 m. Di sela-sela batuan, kini sebagian tertutupi oleh tanah dengan dominansi pasir.

\section{B. Bahan dan Alat Penelitian}

Bahan yang digunakan dalam penelitian ini adalah pupuk kandang, top soil, bibit kaliandra, buni, dan perlengkapan lapangan. Pupuk kandang yang digunakan adalah dari kotoran ayam yang telah mengalami pengomposan dan diperoleh 
dari peternakan terdekat. Bibit tanaman buni merupakan bibit siap tanam berumur satu tahun yang diperoleh dari persemaian Kebun Raya Bali. Bibit tanaman kaliandra disiapkan langsung melalui kegiatan persemaian di Denpasar dan berumur tiga bulan.

\section{Metode Penelitian}

\section{Rancangan Penelitian}

Ujicoba dilakukan dengan rancangan acak lengkap berblok. Terdapat tiga blok dan masing-masing terdiri dari empat tingkat perlakuan. Perlakuan yang diberikan adalah penambahan media lokal/asli pada lubang tanam menggunakan (i) pupuk kandang, (ii) top soil, (iii) pupuk kandang + top soil, dan (iv) kontrol. Jumlah bibit yang digunakan sebanyak 1.200 batang untuk jenis C. calothyrsus dan 96 batang untuk jenis $A$. bunius.

Kegiatan penanaman diawali dengan persiapan lahan berupa pembuatan lubang tanam dengan ukuran 50 × 50 × 50 $\mathrm{cm}$. Jarak tanam antar tanaman buni dibuat dengan ukuran $4 \times 3 \mathrm{~m}$ dan di antara tanaman buni ditanam kaliandra dalam suatu baris dengan jarak antar tanaman kaliandra adalah $0,5 \mathrm{~m}$ dan ukuran lubang tanamnya $30 \times 30 \times 30 \mathrm{~cm}$. Selanjutnya dilakukan penambahan dan pencampuran top soil dan atau pupuk kandang pada lubang tanam, sesuai rancangan percobaan penanaman. Dosis pupuk kandang maupun top soil yang digunakan adalah 10 kg/lubang tanaman buni dan $2 \mathrm{~kg} / \mathrm{lubang}$ tanaman kaliandra, disesuaikan dengan ukuran lubang tanamnya. Pemberian dilakukan dua minggu sebelum penanaman (Drajat et al., 2006).

Proses penanaman dilakukan pada saat lahan sudah siap dan dilakukan pada awal musim hujan. Tanaman dalam polybag ditanam dengan membuka polybag menggunakan pisau tajam (cutter) agar gumpalan tanah dalam polybag tidak rusak. Bibit diletakkan pada lubang secara tegak, kemudian dilakukan pengurugan dengan tanah di sekitarnya yang telah di- gemburkan. Urugan dipadatkan dengan tekanan yang cukup.

\section{Analisis Data}

Pengamatan tinggi dan diameter tanaman dilakukan tiap tahun. Hasil pengukuran tinggi dan diameter dianalisis secara statistik menggunakan perangkat lunak SAS 6.12. untuk menghasilkan analisis keragaman (ANOVA) dan bila diperlukan dilanjutkan uji beda nyata menggunakan Duncan's Multiple Range Test (DMRT) untuk mengetahui perbedaan antar perlakuan (SAS Institute Inc., 1989). Untuk mengetahui perubahan kondisi tanah sebelun dan setelah adanya penerapan perlakuan, dilakukan analisis tanah terutama terhadap sifat kimia tanah. Pengambilan sampel tanah dilakukan untuk tiap perlakuan sebanyak tiga sampel secara acak pada tiap blok. Selanjutnya sampel tanah dianalisis di laboratorium tanah untuk mengetahui $\mathrm{pH}$, C-organik, total nitrogen, fosfor, kalium, natrium, kalsium, dan magnesium. Untuk mengetahui bentuk dan keeratan hubungan antar faktor kondisi tanah dengan pertumbuhan tanaman sebagai efek perlakuan, dilakukan analisis regresi-korelasi guna menghasilkan koefisien korelasi (Steel dan Torrie, 1993).

\section{HASIL DAN PEMBAHASAN}

\section{A. Hasil Analisis Kimia Tanah}

Hasil analisis sampel tanah pada masing-masing perlakuan seperti tampak pada Tabel 1 menunjukkan bahwa pemberian pupuk kandang mampu meningkatkan kandungan $\mathrm{N}$ dan $\mathrm{P}$ pada tanah masingmasing hingga 46 dan 10 kali lipat dibandingkan kontrol. Peningkatan kandungan unsur makro juga tampak signifikan pada unsur Ca dan Mg. Perubahan inilah yang menyebabkan adanya pertumbuhan tinggi dan diameter yang lebih tinggi pada perlakuan pemberian pupuk kandang.

Kandungan $\mathrm{N}$ dalam tanah selain berasal dari bahan organik juga dapat diperoleh tanaman melalui pengikatan/fiksasi 
Tabel (Table) 1. Analisis kimia tanah pada tiap perlakuan (Soil chemical analysis on each treatment)

\begin{tabular}{lcccccccc}
\hline \multicolumn{1}{c}{ Perlakuan (Treatment) } & $\mathrm{pH}$ & $\begin{array}{c}\text { C-organik } \\
\left(\begin{array}{c}\text {-organic }) \\
(\%)\end{array}\right.\end{array}$ & $\begin{array}{c}\mathrm{N} \text { total } \\
(\%)\end{array}$ & $\begin{array}{c}\mathrm{P}_{2} \mathrm{O}_{5} \\
\text { Olsen } \\
(\mathrm{ppm})\end{array}$ & $\mathrm{K}$ & $\mathrm{Ka}$ Extract Morgan Wolf $(\mathrm{ppm})$ & $\mathrm{Ca}$ & $\mathrm{Mg}$ \\
\hline $\begin{array}{l}\text { Media lokal + pupuk kandang (Local } \\
\text { media + chicken manure) }\end{array}$ & 6,97 & 1,8 & 0,23 & 575,9 & 428,5 & 1760 & 2784 & 512 \\
$\begin{array}{l}\text { Media lokal (Local media) + top soil } \\
\text { Media lokal (Local media ) + pupuk }\end{array}$ & 5,65 & 0,5 & 0,08 & 2,3 & 194,8 & 1880 & 572 & 90 \\
$\begin{array}{l}\text { kandang (chicken manure) + top soil } \\
\text { Media lokal sebagai kontrol (Local }\end{array}$ & 6,52 & 1,2 & 0,16 & 225,6 & 105,7 & 1660 & 2424 & 306 \\
media as control) & 6,48 & 0,5 & 0,005 & 57,1 & 128,0 & 1840 & 344 & 76 \\
\hline
\end{tabular}

oleh mikroorganisme seperti oleh rhizobium pada tanaman kaliandra, atau dari air hujan (Schroth and Sinclair, 2003; Bailley, 1991). Hasil analisis menunjukkan telah terjadi peningkatan kadar $\mathrm{N}$ dalam tanah. Berdasarkan kriteria penilaian sifat kimia tanah dari Puslit Tanah dan Agroklimat (Djaenuddin et al., 1994), kandungan total $\mathrm{N}$ pada kontrol termasuk sangat rendah $(<0,1)$ dan peningkatan terbesar menjadi harkat sedang $(0,21-0,5)$ dijumpai pada perlakuan penambahan pupuk kandang.

Hasil uji korelasi terhadap variabel kimia tanah terhadap pertumbuhan tanaman seperti disajikan pada Tabel 2 menunjukkan hubungan positif yang kuat antara peningkatan kandungan $\mathrm{N}$ dalam tanah dengan pertumbuhan tanaman. Hal ini menunjukkan unsur $\mathrm{N}$ dalam perbaikan kondisi tanah pada lahan bekas erupsi Gunung Batur sangat signifikan dalam meningkatkan pertumbuhan tanaman. Tabel 2 menunjukkan tanaman $A$. bunius pertumbuhan tinggi dan diameternya memiliki korelasi terkuat dengan kandungan N. Pada tanaman C. calothyrsus, mesikupun korelasinya bukan merupakan yang tertinggi namun korelasi kandungan $\mathrm{N}$ tersebut masih tergolong sangat tinggi terhadap pertumbuhan tinggi dan diameternya.

Dari segi fisiologis, unsur $\mathrm{N}$ merupakan hara makro esensial yang sangat berperan pada reduksi metabolit nitrat menjadi ammonia, dan asimilasi ammonia menjadi asam glutamat dalam proses pembentukan protein dan penyusun bobot tanaman (Bailey, 1991). Penelitian yang dilakukan oleh Puri dan Swamy (2001) menunjukkan adanya penambahan biomassa yang signifikan sebagai akibat aplikasi nitrogen. Kontribusi terbesar adalah biomassa pada daun, diikuti pada akar dan batang.

Tabel 2. Uji korelasi unsur kimia tanah dengan pertumbuhan tanaman (correlation test between soil chemical elements and plant growth)

\begin{tabular}{c|c|c|c|c}
\hline \multirow{2}{*}{} & \multicolumn{2}{|c|}{ C. calothyrsus } & \multicolumn{2}{c}{ A. bunius } \\
\cline { 2 - 5 } & $\begin{array}{c}\text { Tinggi } \\
\text { (Height })\end{array}$ & Diameter & $\begin{array}{c}\text { Tinggi } \\
\text { (Height })\end{array}$ & Diameter \\
\hline $\mathrm{pH}$ & 0,62 & 0,72 & 0,02 & 0,38 \\
\hline $\mathrm{C}_{\text {organic }}$ & 0,87 & 0,99 & 0,62 & 0,83 \\
\hline $\mathrm{N}_{\text {total }}$ & 0,83 & 0,95 & 0,84 & 0,95 \\
\hline $\mathrm{P}$ & 0,93 & 0,98 & 0,51 & 0,71 \\
\hline $\mathrm{K}$ & 0,97 & 0,82 & 0,47 & 0,45 \\
\hline $\mathrm{Ca}$ & 0,71 & 0,92 & 0,71 & 0,93 \\
\hline $\mathrm{Mg}$ & 0,88 & 0,99 & 0,64 & 0,84 \\
\hline $\mathrm{Na}$ & $-0,21$ & $-0,53$ & $-0,42$ & $-0,73$ \\
\hline
\end{tabular}

Unsur fosfor (P) yang juga merupakan unsur hara utama bagi tanaman tersedia dalam kriteria jumlah yang tinggi kecuali pada perlakuan penambahan top soil. Fosfor yang tersedia dalam jumlah cukup akan memacu perkembangan akar. Hal ini penting terutama pada lokasi dimana pertumbuhan akar sering terhambat oleh batuan dalam tanah seperti pada lokasi di Gunung Batur. Peningkatan unsur $\mathrm{P}$ juga berkorelasi kuat terutama pada pertumbuhan kaliandra, dan sedikit lebih lemah pada buni.

Secara fisiologis unsur $\mathrm{P}$ ini penting perannya dalam proses fotosintesis, perubahan karbohidrat dan senyawa lain yang berhubungan dengan glikolisis dan metabolisme. Dalam metabolisme tanam- 
an, $\mathrm{P}$ memegang peranan langsung dalam transfer dan penyimpanan energi serta merupakan aktifator berbagai enzim sehingga kekurangan unsur ini akan mengakibatkan gangguan hebat pada tanaman (Bailey, 1991; Winarso, 2005).

Kalsium (Ca) termasuk unsur hara esensil sekunder yang diperlukan tanaman meskipun tidak sebanyak seperti pada unsur hara esensil primer $(\mathrm{N}, \mathrm{P}, \mathrm{K})$. Unsur ini diserap tanaman dalam bentuk kation $\mathrm{Ca}^{2+}$. Hasil analisis sampel tanah menunjukkan ketersediaan unsur Ca cenderung meningkat dengan adanya penambahan pupuk kandang dari taraf rendah menjadi sedang. Secara fisiologis unsur ini berperan dalam pembentukan lamella tengah sel dan memainkan peran esensial pada membran sel sehingga defisiensi unsur ini akan mengakibatkan kerusakan pada struktur membran yang akan menghambat pertumbuhan pucuk-pucuk akar, daun, dan jaringan penyimpanan. Gejala di lapangan yang dapat ditemui akibat defisiensi unsur ini adalah perakaran yang jelek (tidak normal) dan matinya titiktitik tumbuh tanaman (Bailey, 1991; Winarso, 2005).

Magnesium (Mg) merupakan satusatunya mineral penyusun klorofil sehingga memegang peran penting dalam proses fotosintesis. Mg juga diperlukan tanaman dalam kegiatan enzim-enzim yang berhubungan dengan metabolisme karbohidrat dan siklus asam sitrat pada proses respirasi sel. Defisiensi Mg akan menghambat sintesis protein dan gejala yang biasa ditemukan adalah daun-daun yang menguning, kecoklatan, dan kemerahan (Bailey, 1991). Sampel tanah yang dianalisis menunjukkan kandungan $\mathrm{Mg}$ yang meningkat dari kriteria rendah menjadi sedang pada perlakuan pemberian pupuk kandang. Seperti halnya pada unsur Ca, korelasi yang kuat ditemukan antara peningkatan unsur $\mathrm{Mg}$ dengan pertumbuhan tanaman terutama pada variabel diameter batang.
Penelitian yang dilakukan oleh Zingore et al. (2008) menunjukkan bahwa pemberian pupuk kandang mampu memelihara kesuburan tanah berpasir melalui peningkatan kandungan bahan organik, $\mathrm{P}$ tersedia, $\mathrm{K}, \mathrm{Ca}, \mathrm{Mg}$, dan unsur mikro dalam tanah. Peningkatan bahan organik meskipun dalam jumlah yang kecil namun dapat memperbaiki sifat tanah lainnya. Menurut Hardjowigeno (2003), peningkatan ini dapat memperbaiki struktur tanah, porositas, penambahan unsur $\mathrm{N}, \mathrm{P}, \mathrm{S}$, unsur mikro lain dan meningkatkan kemampuan tanah menahan air serta peningkatan kapasitas tukar kation.

Pemberian pupuk kandang seringkali juga diikuti oleh perbaikan sifat fisika tanah dengan keuntungan berupa turunnya aliran permukaan dan erosi, dan efek ini dapat bertahan beberapa tahun setelah pemberian (Gilley dan Risse, 2000). Menurut Mowidu (2001), pemberian 20-30 ton/ha bahan organik berpengaruh nyata dalam meningkatkan porositas total, jumlah pori berguna, jumlah pori penyimpan lengas dan kemantapan agregat serta menurunkan kerapatan zarah, kerapatan bongkah dan permeabilitas. Ditambahkan pula oleh Sugito et al. (1995) bahwa pemberian pupuk kandang sebanyak 75 ton/ha per tahun selama 6 tahun berturutturut dapat meningkatkan $4 \%$ porositas tanah, $14,5 \%$ volume udara tanah pada keadaan kapasitas lapangan dan 33,3\% bahan organik serta menurunkan kepadatan tanah sebanyak 3\%.

\section{B. Pertumbuhan Tanaman}

\section{Kaliandra}

Pengukuran tinggi dan diameter terhadap tanaman buni dan kaliandra dilakukan tiap tahun hingga tahun 2010. Hasil pengukuran tersebut tampak seperti pada Gambar 1.

Pada Gambar 1, terlihat bahwa perlakuan pemberian pupuk kandang menghasilkan tinggi dan diameter tanaman terbesar pada akhir pengamatan, yaitu masingmasing 181,7 cm dan 2,1 cm. Jika dibandingkan dengan kontrol, pemberian pu- 
puk kandang pada tanaman kaliandra mampu meningkatkan pertumbuhan tinggi sebesar $51 \%$ dan meningkatkan pertumbuhan diameter sebesar $75 \%$. Gambaran umum perkembangan pertumbuhan tanaman kaliandra pada tiap tahunnya dapat dilihat pada Gambar 2.

Hasil analisis keragaman (ANOVA) pada hasil pengukuran tinggi dan diameter tanaman kaliandra menunjukkan bahwa perlakuan pupuk kandang memberikan pengaruh yang sangat nyata pada tingkat kepercayaan 99\%. Hasil uji lanjut Duncan menunjukkan bahwa hingga umur tiga tahun, perlakuan pemberian pupuk kandang memberikan pertumbuh- an terbaik, berbeda nyata dibandingkan perlakuan lainnya, baik dalam hal tinggi maupun diameter seperti terlihat pada Tabel 3.

Kaliandra merupakan salah satu leguminosa pohon atau semak yang memiliki beberapa spesies, satu di antaranya yang paling banyak dikenal adalah jenis kaliandra bunga merah (Calliandra calothyrsus). Pada sebaran alaminya, tanaman ini tumbuh pada ketinggian 0-1.860 m dengan rerata curah hujan tahunan 1.000$4.000 \mathrm{~mm}$, rerata suhu minimum tahunan $18-22^{\circ} \mathrm{C}$. Selain itu tanaman ini juga toleran terhadap berbagai jenis tanah termasuk

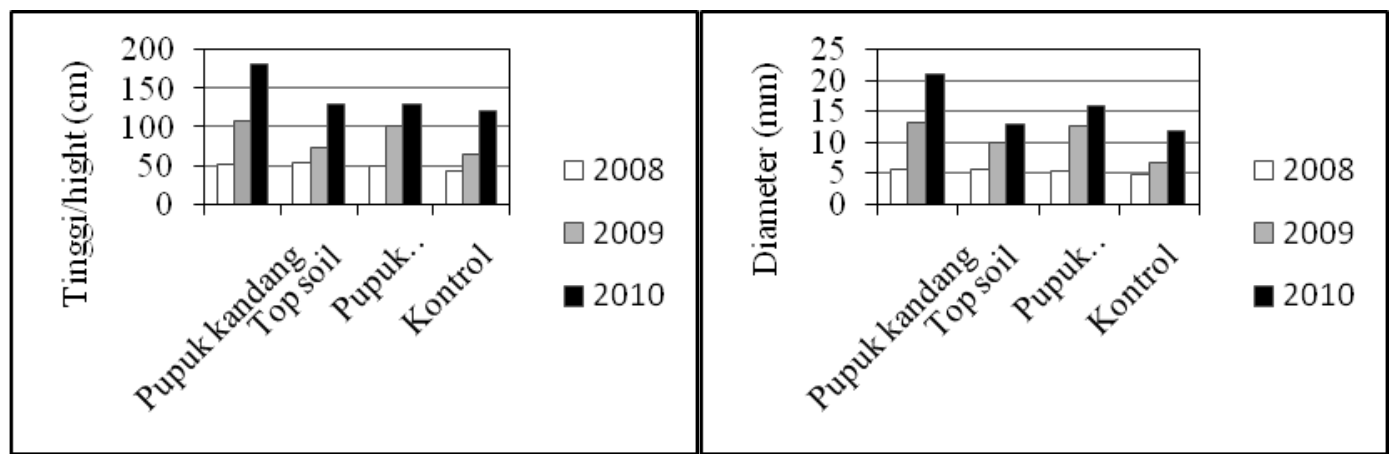

Gambar (Figure) 1. Tinggi dan diameter C. calothyrsus pada tiap tahun pengamatan (Height and diameter of C. calothyrsus for each year observation)

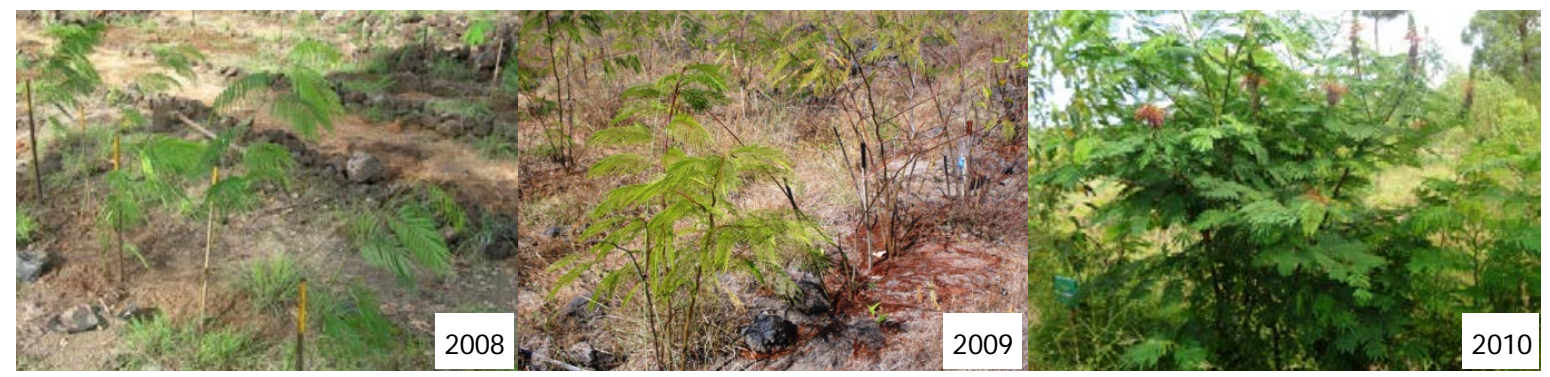

Gambar (Figure) 2. Perkembangan pertumbuhan C. calothyrsus (Growth development of C. Calothyrsus)

Tabel (Table) 3. Uji jarak berganda Duncan terhadap tinggi dan diameter tanaman C. calothyrsus umur tiga tahun (Duncan Multiple Range Test of height and diameter of three years old C. calothyrsus)

\begin{tabular}{lcc}
\hline \multicolumn{1}{c}{ Perlakuan (Treatment) } & Tinggi (Height) (cm) & Diameter (cm) \\
\hline Media lokal + pupuk kandang (Local media + chicken manure) & $181,7 \mathrm{a}$ & $2,1 \mathrm{a}$ \\
Media lokal (Local media) + top soil & $129,1 \mathrm{~b}$ & $1,3 \mathrm{~b}$ \\
Media lokal (Local media ) + pupuk kandang (chicken manure) & $128,2 \mathrm{~b}$ & $1,6 \mathrm{bc}$ \\
+ top soil & & $1,2 \mathrm{c}$ \\
\hline
\end{tabular}


tanah masam dengan $\mathrm{pH} 4,5$. Akan tetapi, C. calothyrsus tidak toleran terhadap tanah tergenang. C. calothyrsus digunakan secara luas oleh Kementerian Kehutanan untuk menghijaukan kembali lahan kritis. Kerapatan pertanaman biasanya 5.00010.000 tanaman per hektar. Pemanenan dilakukan secara berkala untuk menghasilkan daun dan kayu. Tunas tumbuh kembali dengan cepat sehingga dapat melindungi tanah. C. calothyrsus juga digunakan untuk mengubah padang alangalang menjadi sitem silvopastur. C. calothyrsus banyak dimanfaatkan masyarakat Batur sebagai sumber pakan ternak. Daun C. calothyrsus merupakan sumber protein yang baik bagi ternak ruminansia karena mengandung 20-25\% protein kasar yang sangat bermanfaat bagi peningkatan produktivitas ternak. Selain digunakan sebagai hijauan pakan ternak, C. calothyrsus juga banyak dimanfaatkan sebagai kayu bakar, produksi lebah madu, dan untuk konservasi lahan marjinal. C. calothyrsus dimanfaatkan sebagai tanaman untuk konservasi tanah marjinal seperti tepi sungai, hutan, jalan, atau daerah lahan kritis yang ditumbuhi alang-alang (Herdiawan at al., 2005; ICRAF/Winrock, 2000).

Pada C. calothyrsus, perlakuan yang diberikan memberikan kisaran angka ke- mampuan hidup yang tidak jauh berbeda yaitu antara $66,3 \%$ hingga $79,7 \%$. Tabel 4 memperlihatkan bahwa kemampuan hidup tertinggi dijumpai pada tanaman dengan perlakuan pemberian pupuk kandang, kemampuan hidup terendah dijumpai pada kontrol.

Pada akhir musim kemarau sebagian besar tanaman mengalami kekeringan sehingga menggugurkan daun dan bertunas kembali di awal musim hujan. C. calothyrsus dikenal dapat tumbuh cepat dan dapat memperbaiki kondisi kimia dan fisika tanah melalui kemampuannya menyediakan pupuk hijau (Chamberlain, 2001).

\section{Tanaman Buni}

Seperti halnya pada tanaman kaliandra, Gambar 3 menunjukkan pertumbuhan tanaman buni terbaik juga ditemukan pada tanaman yang diberi pupuk kandang, yaitu tinggi dan diameter masingmasing 91,2 cm dan 1,8 cm. Perlakuan ini telah mampu meningkatkan pertumbuhan tinggi sebesar 30\% dan diameter sebesar $13 \%$ dibandingkan kontrol. Secara umum, pertumbuhan tanaman buni pada tiap tahun hingga pada tahun ketiga (2010), terlihat pada Gambar 3.

Tabel (Table) 4. Kemampuan hidup C. calothyrsus pada akhir pengamatan (Survival rate of C. calothyrsus on the last observation)

\begin{tabular}{lc}
\hline \multicolumn{1}{c}{ Perlakuan (Treatment) } & Kemampuan hidup (Survival rate) (\%) \\
\hline Media lokal + pupuk kandang (Local media + chicken manure) & 79,7 \\
Media lokal (Local media) + top soil & 73,3 \\
Media lokal (Local media ) + pupuk kandang (chicken manure) & 71,7 \\
+ top soil & \\
Media lokal sebagai kontrol (Local media as a control) & 66,3 \\
\hline
\end{tabular}
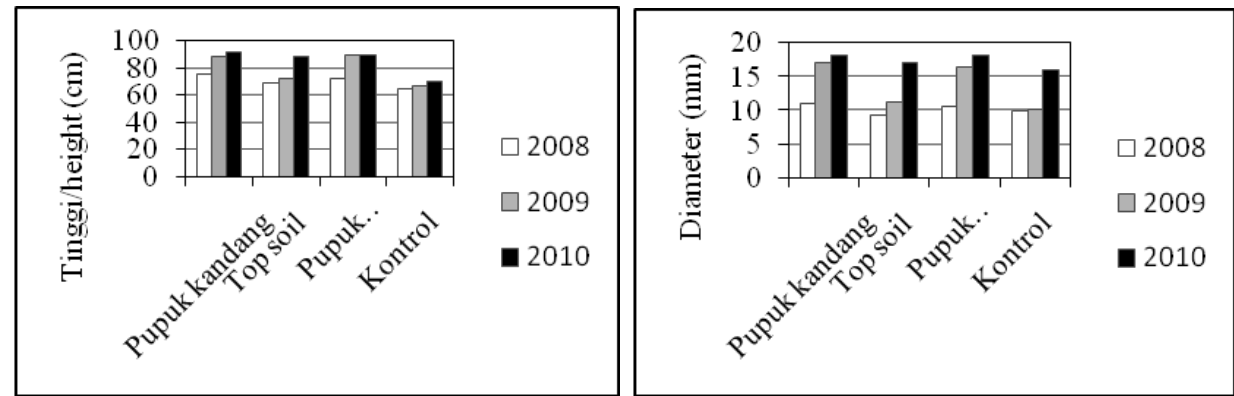

Gambar (Figure) 3. Tinggi dan diameter A. bunius pada tiap tahun pengamatan (Height and diameter of A.bunius for each year observation) 
Pada tanaman buni, analisis keragaman menunjukkan pengaruh yang tidak nyata dari semua perlakuan yang diberikan terhadap tinggi maupun diameter tanaman. Hal ini menunjukkan meskipun perlakuan pemberian pupuk kandang mampu meningkatkan pertumbuhan tinggi dan diameter dibandingkan kontrol, namun peningkatan pertumbuhan ini tidak seresponsif seperti yang terjadi pada tanaman kaliandra. Gambaran umum perkembangan pertumbuhan tanaman buni pada tiap tahunnya disajikan pada Gambar 4 .

Analisis keragaman seperti pada Tabel 5 memperlihatkan adanya pengaruh yang tidak nyata dari semua perlakuan yang diberikan terhadap tinggi maupun diameter tanaman. Hal ini menunjukkan bahwa meskipun perlakuan pemberian pupuk kandang mampu meningkatkan pertumbuhan tinggi dan diameter dibandingkan perlakuan lainnya termasuk kontrol, namun peningkatan pertumbuhan ini tidak seresponsif seperti yang terjadi pada tanaman kaliandra.

Seperti halnya pada tanaman kaliandra, kemampuan hidup tertinggi pada tanaman buni dijumpai pada perlakuan pemberian pupuk kandang yaitu $79,2 \%$, sedangkan kemampuan hidup terendah dijumpai pada kontrol yaitu sebesar 33,3\%, seperti tampak pada Tabel 6 .

Buni (Antidesma bunius (L.) Spreng.) dengan nama lokal buni (Melayu), wuni, atau huni (Sunda) tumbuh liar di daerah-daerah basah di India, Sri Lanka, Burma, dan Malaysia. Buni dapat

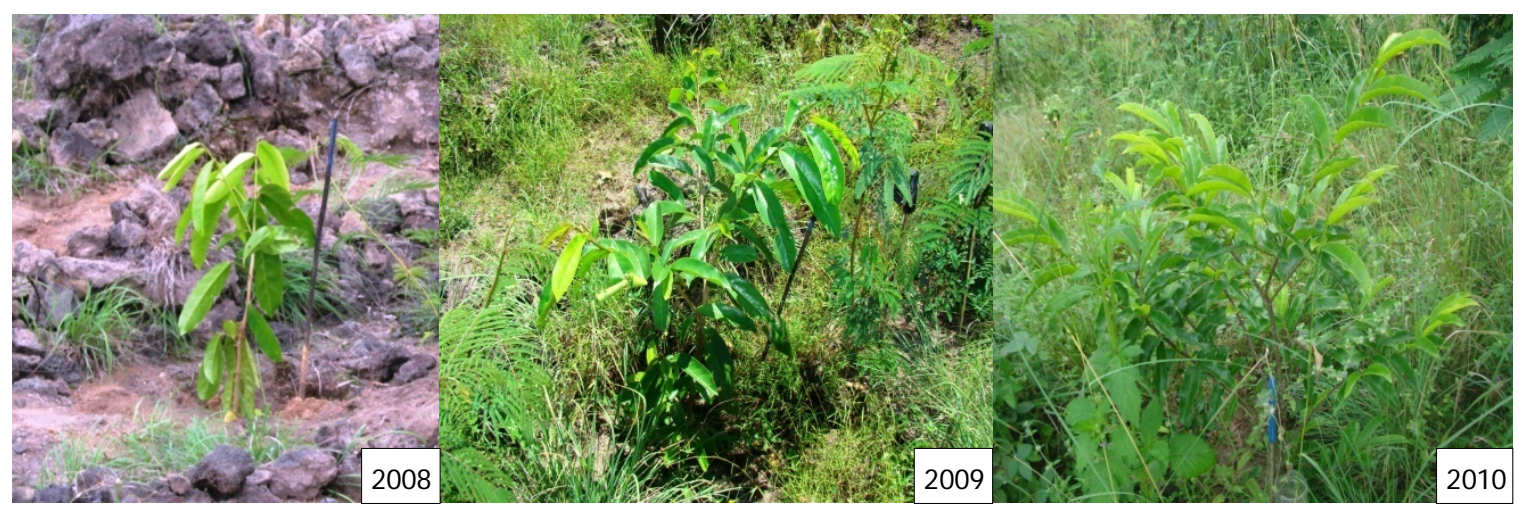

Gambar (Figure) 4. Perkembangan pertumbuhan A. bunius (Growth development of A. bunius)

Tabel (Table) 5. Uji jarak berganda Duncan terhadap tinggi dan diameter tanaman A. bunius umur tiga tahun (Duncan Multiple Range Test of height and diameter of three years old A. bunius)

\begin{tabular}{lcc}
\hline \multicolumn{1}{c}{ Perlakuan (Treatment) } & Tinggi (Height) (cm) & Diameter (cm) \\
\hline Media lokal + pupuk kandang (Local media + chicken manure) & $91,2 \mathrm{a}$ & $1,8 \mathrm{a}$ \\
Media lokal (Local media) + top soil & $88,5 \mathrm{a}$ & $1,7 \mathrm{a}$ \\
Media lokal (Local media ) + pupuk kandang (chicken manure) & $89,6 \mathrm{a}$ & $1,8 \mathrm{a}$ \\
+ top soil & & $1,6 \mathrm{a}$ \\
\hline
\end{tabular}

Tabel (Table) 6. Kemampuan hidup A. bunius pada akhir pengamatan (Survival rate of A. bunius on the last observation)

\begin{tabular}{lc}
\hline \multicolumn{1}{c}{ Perlakuan (Treatment) } & Kemampuan hidup (Survival rate) (\%) \\
\hline Media lokal + pupuk kandang (Local media + chicken manure) & 79,2 \\
Media lokal (Local media) + top soil & 41,7 \\
Media lokal (Local media ) + pupuk kandang (chicken manure) & 79,2 \\
+ top soil & \\
Media lokal sebagai kontrol (Local media as control) & 33,3 \\
\hline
\end{tabular}


tumbuh mulai dari dataran di atas permukaan laut hingga ketinggian $1.400 \mathrm{~m}$ dpl. Tumbuhan ini biasanya menjadi ciri khas sedang berlangsungnya proses suksesi tahap awal sebuah hutan sekunder, dan berperan penting dalam proses reklamasi lahan-lahan terdegradasi sehingga dapat dikategorikan sebagai tumbuhan perintis/pionir. Masyarakat memanfaatkan buah buni yang matang untuk dimakan segar, dibuat selai atau sirop. Cairan buahnya meninggalkan bekas warna merah di jari dan mulut. Daun muda rasanya sedikit asam, dapat disayur atau dimakan mentah sebagai lalap. Kulit batang dan daun mengandung alkaloid yang berkhasiat obat, walaupun menurut beberapa laporan juga dapat beracun (Verheij dan Coronel, 1992).

Pada tanaman buni, kemampuan hidup hingga akhir pengamatan mencapai 53\% dimana kematian terbanyak terjadi saat puncak musim kemarau, meskipun kelembaban tanah telah dijaga melalui penyiraman dengan sistem tetes menggunakan botol plastik terhadap semua tanaman. Banyaknya kematian tanaman ini menunjukkan ketersediaan air lebih besar pengaruhnya terhadap kemampuan hidup tanaman, dibandingkan perlakuan yang dicobakan.

Kesuburan tanah merupakan salah satu penentu pertumbuhan tanaman. Tingkat kesuburan banyak dipengaruhi oleh keberadaan bahan organik, ini tidak saja berperan dalam penyediaan hara tanaman, namun yang jauh lebih penting adalah kemampuannya dalam perbaikan sifat fisik, biologi dan sifat kimia tanah (Atmojo, 2003). Sifat tanah di lokasi penelitian yang didominasi pasir, dan rendahnya kadar lempung serta bahan organik menyebabkan rendahnya ion exchange capacity (IEC) dan water holding capacity (WHC). Nutrisi yang dibutuhkan tanaman biasanya menempel pada partikel tanah dan untuk dapat tersedia bagi tanaman harus berada dalam bentuk larutan sehingga mutlak membutuhkan air. Dalam bentuk larutan inilah nutrisi diserap oleh akar secara difusi mengikuti aliran transpirasi tanaman (Farida, 2007).

Secara umum terlihat bahwa pemberian pupuk kandang, baik dengan atau tanpa top soil memberi respon yang lebih baik dibandingkan pemberian top soil atau kontrol. Dalam hal ini pupuk kandang berperan dalam memperbaiki kualitas tanah secara fisik maupun kimia. Hal tersebut mutlak diperlukan untuk mengatasi keterbatasan kondisi tanah di lokasi yang berjenis Entisol. Secara umum Entisol mempunyai sifat fisik dan kimia yang kurang baik bagi pertumbuhan tanaman. Hal tersebut dikarenakan struktur tanahnya lepas, porositas aerasi besar dan permeabilitas cepat. Selain itu kadar lempung dan bahan organiknya rendah, menyebabkan kapasitas menahan air dan unsur hara rendah, agregasi dan kemantapan agregat rendah. Oleh sebab itu perbaikan sifat tanah dengan penambahan bahan organik dan penyediaan air yang cukup merupakan hal yang tepat, guna mengatasi penghambat utama jenis tanah yaitu sifat fisik disertai kurangnya air (Komar, 1984).

\section{KESIMPULAN DAN SARAN}

\section{A. Kesimpulan}

Penggunaan pupuk kandang dapat memperbaiki kondisi tanah yang menunjang pertumbuhan tanaman kaliandra dan buni di lahan yang tertutup material erupsi Gunung Batur. Pemberian pupuk kandang dengan dosis $10 \mathrm{~kg} /$ lubang tanam mampu meningkatkan kandungan unsur hara tanah terutama N, P, Ca, dan Mg dan berkorelasi kuat dengan pertumbuhan tanaman.

\section{B. Saran}

Penetapan waktu tanaman yang tepat dan penerapan teknik pemeliharaan kelembaban tanah perlu diterapkan untuk menunjang kemampuan hidup tanaman terutama di awal masa pertumbuhan. 


\section{DAFTAR PUSTAKA}

Atmojo, S.W. (2003). Peran bahan organik terhadap kesuburan tanah dan upaya pengelolaannya (Pidato pengukuhan guru besar ilmu kesuburan tanah). Universitas Sebelas Maret, Fakultas Pertanian. Surakarta: Sebelas Maret University Press.

Badan Pengelola Gunung Api Batur. (2009). Volcano talks : museum gunung api Batur. Bali: Badan Pengelola Gunung Api Batur.

Bailley, H.H. (1991). Kesuburan tanah. Badan Kerja Sama Ilmu Tanah BKS. Perguruan Tinggi Negeri Indonesia Bagian Barat.

Bappeda Provinsi Bali. (2009). Peta tingkat kekritisan lahan wilayah Provinsi Bali Tahun 2008. Bali: Bappeda Provinsi Bali.

Chamberlain, J.R. (Eds). (2001). Calliandra calothyrsus: an agroforestry tree for the humid tropics (p.100) (Tropical forestry paper no. 40, p.100). Oxford Forestry Research Institute, UK.

Djaenuddin, D., Basuni, Hardjowigwno, S., Subagyo, H., Sukardi, M., Ismangun,... Jordens, E.R. (1994). Kesesuaian lahan untuk tanaman pertanian dan tanaman kehutanan. Bogor: Pusat Penelitian Tanah dan Agroklimat.

Drajat, Bustomi, S., Widodo S., Mindawati, N., Rostiwati, T., Kosasih, A. S., .... Heryati, Y. (2006). Rancangan teknis penanaman dengan sistim silvikultur intensif. Balai Perbenihan Tanaman Hutan Jawa dan Madura, Sekolah Tinggi Penyuluhan Pertanian Bogor, \& Puslitbang Hutan dan Konservasi Alam Bogor.

Farida, E. (2007). Nutrisi dan pertumbuhan tanaman (Diktat mata kuliah Fisiologi Stres Tanaman Tropis). Fakultas Kehutanan UGM, Yogyakarta.

Gilley, J.E., \& Risse, L. M. (2000). Runoff and Soil Loss as Affected by the
Application of Manure. Trans ASAE, (43), 1583-1588.

Hardjowigeno, S. (2003). Ilmu Tanah (p.250). Jakarta: Akademika Pressindo.

Herdiawan, I., Fanindi, A., \& Semali, A. (2008, Maret 13). Karakteristik dan pemanfaatan kaliandra (Calliandra calothyrsus) (pp.140-147). Lokakarya Nasional Tanaman Pakan Ternak Retrieved from: Pusat Penelitian dan Pengembangan Peternakan website: http://balitnak.litbang .deptan.go.id.

ICRAF/Winrock. (2000). Lokakarya Produksi Benih dan Pemanfaatan Kaliandra (p.49). Bogor, Indonesia: International Centre for Research in Agroforestry dan Winrock International.

Komar, M. (1984). Ketersediaan lengas tanah untuk tanaman pada tanah regosol dengan menggunakan tanaman jagung sebagai tanaman uji (Tesis Pasca Sarjana). Universitas Gadjah Mada, Yogyakarta.

Mowidu. (2001). Peranan bahan organik dan lempung terhadap agregasi dan agihan ukuran pori pada entisol (Tesis Pasca Sarjana). Universitas Gadjah Mada, Yogyakarta.

Puri, S \& Swamy, S., L. (2001). Growth and biomass production in Azadirachta indica seedlings in response to nutrients ( $\mathrm{N}$ and $\mathrm{P}$ ) and moisture stress. Agroforestry Systems, (51), 57-68.

Pusat Vulkanologi dan Mitigasi Bencana Geologi. (2011, January 20). Penurunan status kegiatan gunung api Batur dari waspada menjadi normal. Retrieved from: http://www .vsi.esdm.go.id.

SAS Institute Inc. (1989). SAS user's guide : Statistic $\left(5^{\text {th }}\right.$ ed). Cary, NC : SAS Institut Inc.

Schroth and Sinclair (Eds). (2003). Trees, crops and soil fertility : Concepts and research methods. Cambridge: CABI Publishing. 
Steel, R.G.D. \& Torrie, J.H. (1993). Prinsip dan prosedur statistika. Jakarta: PT. Gramedia Pustaka Utama.

Sugito, Y., Nuraini, Y., \& Nihyati, E. (1995). Sistem pertanian organik. Malang: Fakultas Pertanian Universitas Brawijaya.

Supriyanto. (2002). Rehabilitasi lahan bekas pertambangan emas : memupuk tanah dan bukan memupuk tanaman. Prosiding Diskusi Hasilhasil Litbang Rehabilitasi dan Konservasi Sumberdaya Hutan. Bogor: Puslitbang Hutan dan Konservasi Alam.
Verheij, E.W.M., \& Coronel, R.E. (Eds). (1992). PROSEA 2 : Edible fruits and nuts (pp.78-79). Bogor, Indonesia: Prosea Foundation.

Winarso, S. (2005). Kesuburan tanah: dasar kesehatan dan kualitas tanah. Yogyakarta: Gava Media.

Zingore, S., Delve, R. J., Nyamangara, J., Giller, K. E. (2008). Multiple benefits of manure: The key to maintenance of soil fertility and restoration of depleted sandy soils on African smallholder farms. Nutr Cycl Agroecosyst, (80), 267-282. 